\title{
A Fugacity Based Model for the Assessment of Pollutant Dynamic Evolution of VOCS and BTEX in the Olt River Basin (Romania)
}

\author{
ANDREEA IORDACHE ${ }^{1}$, MIHAELA IORDACHE ${ }^{1}$, CLAUDIA SANDRU ${ }^{1}$, CEZARA VOICA ${ }^{2}$, DIANA STEGARUS ${ }^{1}$, \\ RAMONA ZGAVAROGEA ${ }^{1}$, ROXANA ELENA IONETE ${ }^{1 *}$, SIMONA COTORCEA (TICU) ${ }^{3}$, MARIUS GHEORGHE MIRICIOIU ${ }^{1 *}$ \\ ${ }^{1}$ National Research and Development Institute for Cryogenics and Isotopic Technologies -ICSI Rm. Valcea, 4 Uzinei Str., 240050, \\ Rm. Valcea, Romania \\ ${ }^{2}$ National Institute for Research and Development of Isotopic and Molecular Technologies, 67-103 Donat Str., Cluj-Napoca, \\ Romania \\ ${ }^{3}$ Politehnica University of Bucharest, Faculty of Applied Chemistry and Material Science, Analytical Chemistry and Environmental \\ Engineering Department, 1-7 Polizu Str., 011061, Bucharest, Romania
}

\begin{abstract}
An important tributary of the Danube River, the Olt River, was characterized in its middle and lower catchment in terms of volatile organic compounds (1,2-dichloroethane and perchlorethylene) and volatile aromatic hydrocarbons (benzene, toluene and xylene isomers) to better assess their transfer in the environmental compartments (air, water, sedimentand biota). A fugacity based calculation model was applied to establish the bio-concentration factors (BCFs) that relates the compounds concentration from sediment-, water- or air- to the biota based on experimental data. Thus, conclusive suggestions can be achieved for a rapid preliminary risk assessment as support tool for the preventive measures in the contaminated areas resulting from accidental chemical discharges or continuous pollution. For thus, water and sediment samples were collected and analyzed by gas chromatography for the selected compounds, the results being applied as input data for the model. The modeling revealed the tendency of the investigated compounds to transfer from water section to air. Simulated values obtained for section sediment as validation tool, are comparable and compatible with the values obtained by analytical measurements, and thus a rapid estimation of the pollution level in the environmental compartment of interest can be achieved based on a limited number of analytical measurements. Thus, by applying the fugacity model to estimate a pollution footprint, conclusive indications for a rapid environmental risk assessment can be achieved.
\end{abstract}

Keywords: volatile organochlorine substances, volatile aromatic hydrocarbons (BTEXs), MacKay model, fugacity, ecosystem

Environmental pollution with hazardous substances occur mainly due to wastewater discharges from point sources and diffuse emission sources containing nonsynthetic pollutants (heavy metals) and/or synthetic pollutants (organic micro-pollutants). Hazardous substances produce toxicity, persistence and bioaccumulation in the aquatic environment. Volatile organic compound are widely used in industry, given their evaporation ability after use. The large amounts of organochlorine substances are obtained during the chlorination of drinking water and wastewater. Although it was found that are over 200 natural halogenated hydrocarbons, most chlorinated compounds into the environment are of anthropogenic origin [1]. As these substances progresses in the food chain, their concentration increases the risks to human and ecosystem following the same trajectory. Therefore, the control of emissions of these substances, even when they are in very small amounts may become a necessity [2-4].

The level of contamination resulting from accidental or continuous chemical discharges was usually assessed using the transfer models on environmental compartments. These models are mainly based on a single environmental compartment, such as the transfer of a contaminant in water. However, the chemicals that are released into the environment, succeed through various compartments of the environment as a result of complex processes physico- chemical and biological [5-8]. One such model is the Mackay model $[9,10]$, which uses patterned backgrounds to explore the possible behaviour of the chemical and thus may estimate the level of pollution with hazardous chemicals to environmental water, sediment, and biota. This model can give conclusive hints for a rapid risk assessmenton which to supportconclusions on the pollution preventive measures. Effective management requires understanding of the environment and the ability to analyze quantitative risk transfer mechanism associated to health and chemical contamination.

Environmental models are important tools in understanding the behavior of contaminants in complex environments. They are used to simulate chemical transport with focus on a single medium and multimedia fate models, allowing to calculate the chemical behavior in various environmental compartments. The multimedia fate model (MFM), as originally developed by Mackay [11], is a general multimedia model that has been applied to various environmental systems [12] and has proven its usefulness in understanding the relations among different media. How ever, the general MFM is based on a box model that does not consider spatial variability. To combine the advantages of the single-medium model and the general MFM, previous studies have suggested watershed-based spatially resolved multimedia fate models based on an integration of a grid-based air advection model and a polygon shape watershed-based multimedia model.

The first level (Level I) of calculation evaluates the equilibrium distribution of fixed quantity of chemical between the compartments in a closed evaluative or unit world' environment, i.e. equifugacity applies. It is a steady state calculation with no inflow, outflow, intermedia transport or degrading reactions. Output from the Level I

* email: roxana.ionete@icsi.ro; marius.miricioiu@icsi.ro, Phone: 0040250732744 
calculation indicates the phases or media into which a chemical is likely to partition. It also provides equilibrium concentrations of the chemical in each compartment of the model environment and thus shows the media where concentrations are likely to be highest (i.e. the fugacity capacity, $Z$, is largest) and where the masses are highest (i.e. VZ is largest, where $V$ is the compartment volume and $Z$ is the corresponding $Z$ value).

In 1983, a set of two papers was published describing simple models of chemical fate in lakes and rivers [13], namely the QWASI (Quantitative Water Air Sediment Interaction) models. The models were compiled using the fugacity concept and have been made freely available as software from the website of the Canadian Centre for Environmental Modelling and Chemistry (CEMC) and have been widely applied to specific environmental systems [14, 15]. Chemical inputs are by direct emissions, adventive inflows of water and suspended particles, and deposition from an atmospheric compartment with a defined concentration by wet and dry aerosol and gaseous deposition. Steady state mass balance equations are compiled separately for the water and sediment compartments with chemical masses and concentrations expressed as fugacities in water and in sediment. Although the model simulates a steady state condition it can be adapted to treat dynamic conditions as a pair of first order differential equations that can be solved analytically or numerically [16, 17].

In previous studies [16-18] we described an updated state of the science EQuilibrium Criterion (EQC) model that is used to provide a screening level evaluation of the likely fate of a chemical that is introduced into a multimedia environment by various modes of entry.

This work focuses on a fugacity based calculation model useful to assess the bio-concentration factors (BCFs) that relates the pollutant compounds concentration from sediment-, water- or air- to the biota based on experimental data. The application was performed on the Olt River, in its middle and lower catchment, considering the volatile organic compounds (1,2-dicloroethane and perchlorethylene) and volatile aromatic hydrocarbons (benzene, toluene and xylene isomers) in water and sediments as input data to better assess their transfer in other environmental compartments, like air and biota.

\section{Experimental part}

\section{Materials and methods}

Study area and sample collection

The Olt River, the main tributary of the Danube River in Romania, has a total length of $615 \mathrm{~km}$ and from its source in the Eastern Carpathian Mountains (Hasmas orohydrographic node) to its flows in the Danube (at Islaz) pasess relief units with various physical and geographical features (30\% mountains, $53 \%$ hills and $17 \%$ plan). Our study refers to the middle and lower watershed of the Olt River, from Cornetu (North of Valcea county) to Islaz (South - the point of flowing in the Danube). There are 25 cascading dams constructed on the river for flood control, energetic and irrigation purposes, which can considerably affect the river flow. The climatic conditions of the study area are somehow influenced by the varied relief in the catchment of the Olt River and also the anthropogenic activities are diverse.

For this study water and sediment samples were collected in 22 points (Fig. 1), including 19 accumulation lakes, during the springtime of year 2018. The sampling was performed under snow (in March) and rain (in May) conditions also accentuated by the significant rise in temperatures, from an average of $6^{\circ} \mathrm{C}$ in March to $22^{\circ} \mathrm{C}$ in May 2018, which can influence the concentrations of the investigated compounds.

Water samples were collected in polyethylene bottles, at depth between 0.2 and $0.5 \mathrm{~m}$ while sediments were sampled into plastic bags, and preserved by adding a small amount of concentrated nitric acid.

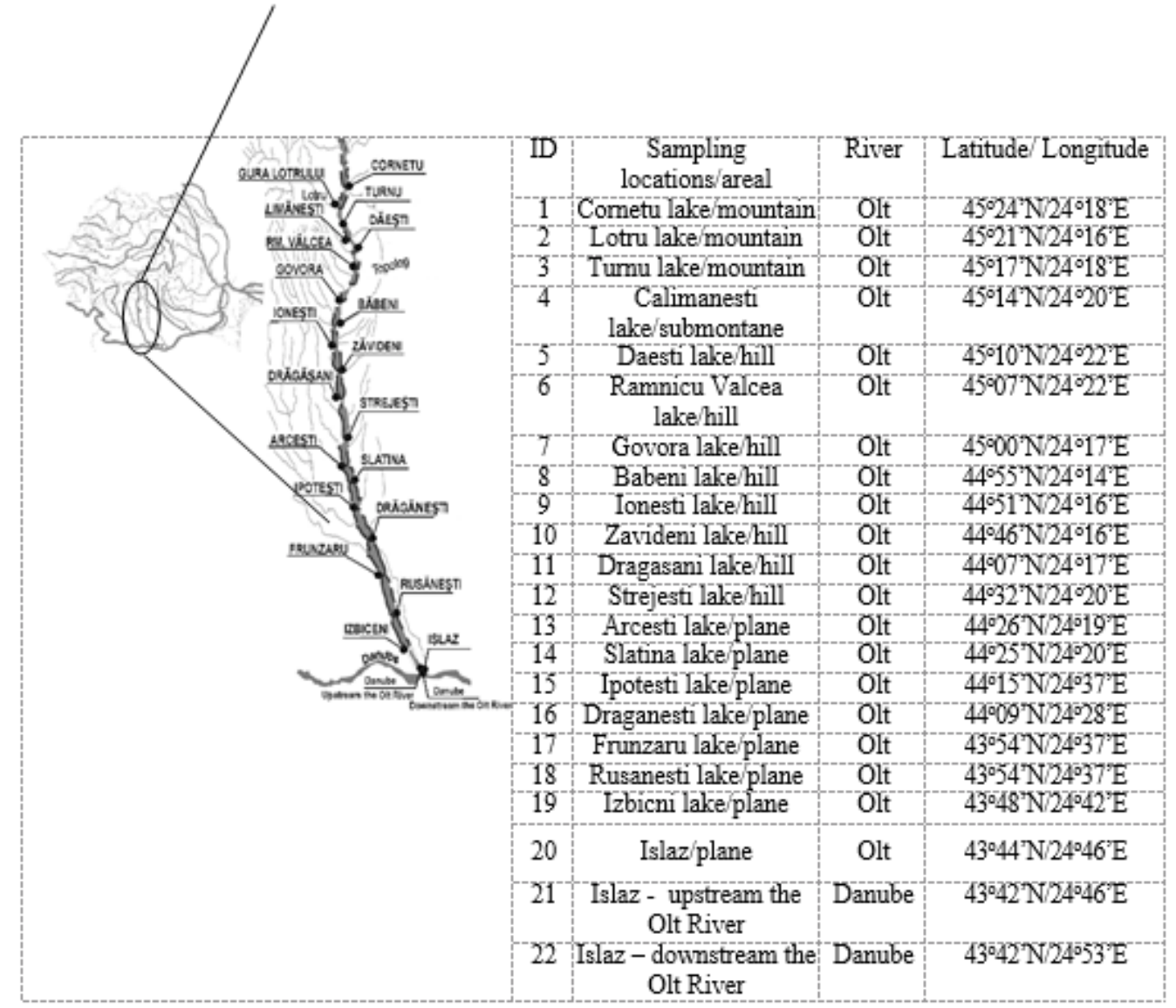

REV.CHIM.(Bucharest) $\$ 70 \diamond$ No. $10 \diamond 2019$
Fig. 1. Investigation area localization of water and sediments sampling points 
Samples collection and chemical analysis

Samples preparation

Concerning the VOCs sample preparation: we took in account $500 \mathrm{~mL}$ of water which was extracted twice with $50 \mathrm{~mL}$ of hexane. The combined extracts were dried over on sodium sulfate and concentrated to $2 \mathrm{~mL}$ with a TURBOVAP concentrator, and then introduced for analysis by GC/MS. For the BTEX water preparation we needed 10 $\mathrm{mL}$ of water which was extracted with $2 \mathrm{~mL}$ of hexane and the extract was dried over sodium sulfate and injected into GC/MS. For sediments no preparation procedure was applied. The samples were directly quantified by contribution of dynamic HEADSPACE GC/MS analysis.

\section{Analytical procedure}

The analytical investigation of the chlorinated organic compounds and BTEX was performed using a Gas Chromatograph coupled with a Mass Spectrometer of 240MS $450 \mathrm{GC}$ Varian. For the chromatographic separation, a TG-WAXMS Polar Chromatographic Column with dimensions of $60 \mathrm{~m} \times 0.32 \mathrm{~mm} \times 0.25 \mu \mathrm{m}$ was used.

For the analysis of chlorinated organic compounds (1,2dichloroethane and perchlorethylene), the oven temperature was maintained at $70^{\circ} \mathrm{C}$ for $0.8 \mathrm{~min}$, increased to $110^{\circ} \mathrm{C}$ at a rate of $3 \% \mathrm{~min}$, then $140^{\circ} \mathrm{C}$ at $3 \% \mathrm{~min}$ and increased to $160^{\circ} \mathrm{C}$ by $1.2^{\circ} / \mathrm{min}$ where the duration was 2 $\mathrm{min}$. In case of volatile aromatic hydrocarbons (benzene, toluene and xylene isomers), the oven temperature was maintained at $40^{\circ} \mathrm{C}$ for $1.2 \mathrm{~min}$, increased to $90^{\circ} \mathrm{C}$ at a rate of $10^{\circ} / \mathrm{min}$ then $120^{\circ} \mathrm{C}$ at $5 \% \mathrm{~min}$ and increased to $200^{\circ} \mathrm{C}$ by $10 \%$ min where the time duration was $10 \mathrm{~min}$.

\section{Model application}

General data regarding the fugacity concept

The multimedia QWASI model was created by the Canadian Centre for Environmental Modelling and Chemistry and is used to calculate the changing trend of chemicals in the environment [19]. How ever, this method is only applicable for chemicals with a measurable vapor pressure. For most nonvolatile chemicals, such as heavy metals, an equivalence approach is used instead. Briefly, the model is based on mass conservation (the water body is well mixed), by means of defining a series of $Z$ values (equivalence capacity, dimensionless) and $D$ values (transfer parameters, $\mathrm{m}^{3} / \mathrm{d}$ ), using Q (equivalence, mole/ $\mathrm{m}^{3}$ ) as the equilibrium criterion, and creating the mass balance equation for the liquid (water), solid (sediment), and air phases under steady or unsteady states.

In order to study the distribution of chemicals in various environmental matrices also a qualitative description of the types of matrices is required, highlighting some of the mostimportant physico-chemical properties. In this sense, averages model are puttogether and could be used later in the calculations. For calculus an area of $1 \mathrm{~km} / 1 \mathrm{~km}$ is considered, including air, water, soils and sediments. These environments have assigned volumes and typical properties, purely illustrative and that, in turn necessitated some changes if was treated chemical evolution in a specific region $[8,9]$.

According to G.N. Lewis [20], the fugacity concept describes the tendency of a chemical transition from one phase to another when they are in contact. It is identical to the concept of ideal gas partial pressure and chemical potential is related to logarithmically, so it varies linearly or non-linearly with concentration. At low partial pressures ideal conditions fugacity is equal to the partial pressure.

Based on the concept of fugacity, one can postulate a nearly linear relationship between fugacity dependence and concentration of the chemical in each environmental compartment (eq.1) [9]:

$$
P_{T} V=n R T
$$

where $Z$ is a constant of proportionality called fugacity capacity with the units $\mathrm{mol} / \mathrm{m}^{3} \mathrm{~Pa}$. This equation implies that $C$ always varies linearly with $f$. Nonlinearity can be adapted by consideration of $Z$ as a function of $C$ or $f$.

Fugacity (Z) for air - The basic equation for the fugacity [9] of a substance in the state of the vapor is:

$$
F=y \times \phi \times P_{T}
$$

where $y$ is the mole fraction of chemicals and fugacity coefficient $\phi$ is $P_{T}$ is the pressure (atmospheric) total.

Considering the law of gases:

$$
P_{T} V=n R T
$$

where $n$ is the total number of moles of air and chemicals present, and $T$ is the absolute temperature, the chemical concentration $C$ (solute) will become:

$$
C=\frac{y P_{T}}{R T}=\left(\frac{1}{\phi R T}\right) f
$$

Thus,

$$
\mathrm{Z} \text { is } \frac{1}{\phi R T}
$$

or

$$
\frac{1}{R T}
$$

when the $\Phi=1$.

Fugacity ( $Z$ ) for water - Fugacity equation for a compound $i$ dissolved in water or another solvent is given in terms of mole fraction $x_{i}$, activity coefficient $\gamma_{\text {, }}$ and reference fugacity $f R$ based on Raoult law as (eq. 7-14):

$$
\begin{gathered}
f_{i}=\frac{n_{i}}{\left(V_{w}+V_{i}\right)} \approx R \\
V_{w}=n_{w} v_{w} \\
x_{w}=\frac{n_{i}}{n_{i}+n_{w}} \approx \frac{n_{i}}{n_{w}}
\end{gathered}
$$

where $i$ - solute, and $w$ - water

$$
\begin{gathered}
C_{i} \approx \frac{x_{i}}{v_{w}} \approx \frac{x_{i}}{\left(18 \times 10^{-6} \mathrm{~m}^{3} / \mathrm{mol}\right)} \\
f_{i}=C_{i} v_{m} y_{i} f R
\end{gathered}
$$

or,

$$
\begin{gathered}
C_{i}=\frac{1}{\left(v_{w} y_{i} f R\right) f_{i}} \\
Z_{i}=\frac{1}{v_{w} y_{i} f R}
\end{gathered}
$$

For a solution in water ZW may be inferred as (eq. 1517):

$$
Z_{w}=\frac{1}{v_{W} y_{i} P_{S_{L}}}
$$




$$
\begin{aligned}
& K_{A W}=\frac{Z_{A}}{Z_{W}}=\frac{H}{R T}=\frac{P_{s}}{C_{s} R T} \\
& Z_{w}=\frac{Z_{A} R T}{H}=\frac{1}{H}=\frac{C_{s}}{P_{s}}
\end{aligned}
$$

(because $Z_{A}=\frac{1}{R T}$ ), $C_{S}$ and $P_{S}$ situation where are values for liquids and solids status.

Fugacity (Z) for the soil or sediment - The simplest method of deduction for $Z$ is correlating him for $Z_{\text {water }}$ using a dimensionless partition coefficient. This coefficient can be determined from several isothermal equations (linear, Langmuir, Freundlich). In most cases the data may be represented, at least at low concentrations of the linear expression (eq. 18):

$$
C_{s}=K_{S W} C_{W}
$$

where $C_{s}$ is the concentration of adsorbed $\left(\mathrm{mol} / \mathrm{m}^{3}\right.$ of sorbent), ${ }^{S} C_{W}$ is the water content. The nonlinear equation $\mathrm{KSW}$ is a function of concentration. $K_{S W}$ is a dimension less partition coefficient.

As is known, concentrations to adsorbed substances are usually expressed as the amount of solute (sorbent) adsorbed per unit mass. $K_{p}$ is defined by units of $\mathrm{L} / \mathrm{kg}$ and $K_{S W}$ is related to the density of sorbent $\rho S$ in I $\mathrm{g} / \mathrm{L}\left(\right.$ or $\mathrm{g} / \mathrm{cm}^{3}$ or $\mathrm{mg} / \mathrm{m}^{3}$ ) as follows:

$$
\begin{gathered}
K_{S W}=\rho_{S} K_{p} \\
K_{S W}=\frac{Z_{S}}{Z_{W}} \\
Z_{S}=Z_{W} K_{S W}=\frac{\rho_{S} K_{P}}{H}
\end{gathered}
$$

Fugacity (Z) for biotic phase (fish)

$$
Z_{B}=\frac{\rho_{B} K_{B W}}{H}
$$

$\rho B$ equals the numerical density of water and can be ignored. It should be recalled, however, in cases where $K_{B W}$ is defined on a dry weight basis (notwetmass), or the concentration in specific tissues such as fat. In these cases, the density is calculated as the mass of biota/dry tissue per unit volume of wet biota. If procedures for estimating the $Z$ values is performed for each environmental situation again, then the equilibrium concentrations can be derived using $f$ as a common criterion of balance.

\section{Results and discussions \\ Model parameters}

Starting from measured values of the investigated pollutants in environmental compartment [22-26] water the transfer of these hazardous pollutants in sediment, biota and air was achieved by modeling. To validate the model, also the measured values obtained for sediment samples were used, as these types of evidence have been worked as real samples in the laboratory. Biota has an approximate quantity of 1 part $/ \mathrm{m}^{3}=7.83 \times 1$ million $107 / 106=78.3$. The input data to the model comprised environmental parameters describing the compartment composition, inter-compartment exchange rates, etc., physicochemical properties of volatile organic compounds (1.2dichloroethane and perchlorethylene) and volatile aromatic hydrocarbons (benzene, toluene and xylene isomers) and emission data. The values of physicochemical properties of volatile organic compounds (1,2 dicloethane and perchlorethylene) and volatile aromatic hydrocarbons (benzene, toluene and xylene isomers) used here were the mean values derived from previous studies [21] or most frequently used in the model calculation. The main physicochemical properties (vapor pressure $\left(P_{s}\right)$, $\mathrm{n}$-Octanol/Water Partition Coefficient $\left(\mathrm{K}_{\mathrm{ow}}\right)$, water-soil partition coefficient $\left(\mathrm{K}_{\text {o.w }}\right)$, organic carbon partition coefficient $\left(K_{f}\right)$, water-soill partition coefficient $\left(K_{d}\right)$ and Henry's law $(\mathrm{H})$, of investigated compounds, used in the modeling are summarized in Tables 1 and 2.

\section{Transfer of COVs to the environment of Olt River}

The mathematical model was applied to the organochlorine substances: 1,2 dichloroethane and perchlorethylene. The results of simulation are highlighted in Fig. 2, highlighted the tendency for the volatile organic compounds, 1,2-dichloroethane and tetrachloroethane, known to be volatile compounds, to accumulate in the air compartment, at values of $65 \%$ for 1,2-dichloroethane and $68 \%$ for perchlorethylene.

Starting from the measured values of these pollutants in the environmental factor water, by applying the fugacity model, the transfer of these hazardous pollutants in environments sediment, biota and air was achieved (Fig. 3). For model validation, the measured values of the pollutants in the sediment samples were used.

Table 1

PHYSICOCHEMICAL PROPERTIES OF VOLATILE ORGANIC COMPOUNDS (1,2 -DICHLOROETHANE AND PERCHLORETHYLENE) [21]

\begin{tabular}{|l|c|c|c|}
\hline Symbol & Unit & $\mathbf{1 , 2}$ - dichloroethane & Perchlorethylene \\
\hline $\mathrm{P}_{\mathrm{g}}$ & $\mathrm{Pa}$ & 8700 & 1900 \\
\hline $\mathrm{K}_{\mathrm{ow}}$ & - & 28.18 & 2511.88 \\
\hline $\mathrm{L}_{\mathrm{og}} \mathrm{K}_{\mathrm{ow}}$ & - & 1.45 & 3.40 \\
\hline $\mathrm{K}_{\mathrm{oc}}$ & - & 38.02 & 95.50 \\
\hline $\mathrm{K}_{\mathrm{d}}$ & - & 0.1901 & 0.4775 \\
\hline $\mathrm{H}$ & $\mathrm{Pa} \cdot \mathrm{m}^{3} / \mathrm{mol}$ & 98.96 & 1529.41 \\
\hline
\end{tabular}

Table 2

PHYSICOCHEMICAL PROPERTIES OF VOLATILE AROMATIC HYDROCARBONS (BENZENE,

TOLUENE AND XYLENE ISOMERS) [21]

\begin{tabular}{|l|c|c|c|c|c|c|c|}
\hline Symbol & Unit & Benzene & Toluene & Ethylbenzene & o-xylene & m-xylene & p-xylene \\
\hline $\mathrm{Ps}$ & $\mathrm{Pa}$ & 10000 & 3780 & 900.0 & 700.0 & 800.0 & 900.0 \\
\hline Kow & - & 125 & 562.34 & 1380.38 & 1318.25 & 1584.9 & 1412.5 \\
\hline Koc & - & 134.9 & 140.0 & 204.0 & 239.9 & 199.52 & 199.50 \\
\hline Kd & - & 0.675 & 0.700 & 1.02 & 1.119 & 0.998 & 0.998 \\
\hline H & $\mathrm{Pa}^{3} / \mathrm{mol}$ & 436.37 & 662.15 & 562.08 & 412.88 & 530.85 & 579.11 \\
\hline
\end{tabular}



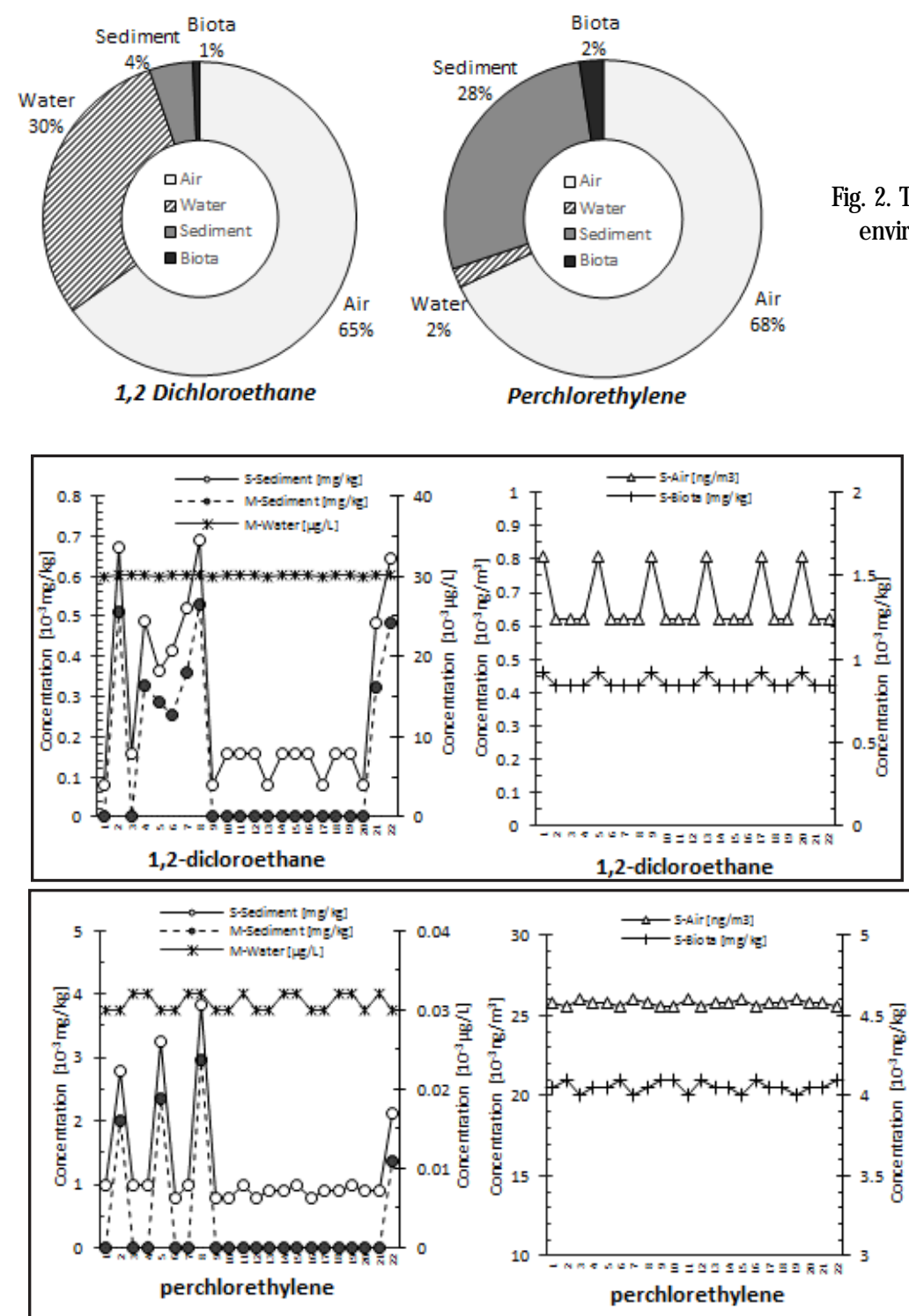

Fig. 2. Transfer of 1, 2 - dichloroethane and perchlorethylene in the environmental compartments (air, water, sediment, and biota)
Fig. 3. Measured/predicted concentration of 1,2dicloroethane and perchlorethylene in environmental compartments
Transfer of 1,2-dichloroethane - the values obtained for the environmental sediment in the modelling transfer of 1,2-dichloroethane from water was very similar to those determined experimentally in the measurement campaigns: e.g. $0.00016 \mathrm{mg} / \mathrm{kg}$ by simulation, $<0.0001$ $\mathrm{mg} / \mathrm{kg}$ (the detection limit of the method) by measurement. As overall observation, the simulated values of 1,2dichloroethane concentration in sediment (e.g. 0.00016 $\mathrm{mg} / \mathrm{kg}$ ) were slightly higher than those determined experimentally during the measurement campaign, of $<0.0001 \mathrm{mg} / \mathrm{kg}$ (the detection limit of the method). However, these shapes with a good enough uncertainty levels in this type of substance in this sediment sampling, indicating an average concentration level of $<0.0001 \mathrm{mg} /$ $\mathrm{kg}$. From the modelled values was observed a tendency by transfer of 1,2-dichloroethane in the section air, with values between $0.030-0.03017 \mathrm{ng} / \mathrm{m}^{3}$; insignificant amount is taken from the biota compartment, with values between 0.001 to $0.00084 \mathrm{mg} / \mathrm{kg}$.

Transfer of Perchlorethylene - the values obtained for the environment al sediment in the modelling transfer of perchlorethylene in water are close to those determined experimentally (e.g. between $0.001 \mathrm{mg} / \mathrm{kg}$ and $0.00078 \mathrm{mg} /$ $\mathrm{kg}$ by simulation to $<0.001 \mathrm{mg} / \mathrm{kg}$ and 0.0036 by measurement). The values obtained from measurements were slightly lower than the simulated ones for the transfer of perchlorethylene from water to sediment From the modelled values was observed a tendency by transfer of this pollutantin the section air, with values between 0.02561 to $0.0026 \mathrm{ng} / \mathrm{m}^{3}$; insignificant amount is taken from the biota compartment, with average value of $0.004055 \mathrm{mg} / \mathrm{kg}$.

The transfer of BTEXs compounds in the environment of Oltriver

The mathematical model was developed for analysis of benzene $(B)$, toluene $(T)$, ethylbenzene $(E)$, and isomeric ( $O$-, $m-, p$-) xylenes $(X)$. The values of the modelling are presented in figure 4. Was observed that the volatile aromatic hydrocarbons (BTEXs) have a transfer tendency in the air of $84.3 \%$ for benzene, $77 \%$ for toluene, $58 \%$ for $\mathrm{m}$-xylene, $57 \%$ for ethylbenzene, $53 \%$ for $m$-xylene and $51 \%$ for o-xylene.

Starting from the measured values of these pollutants in environmental factor water was achieved by modelling their transfer to the environmental compartments sediment, biota and air. Of course, to validate the model, real values obtained by measurements for sediment, were considered. The obtained results are presented for each sampling pointin figure 5-10.

For benzene (Fig. 5), the values obtained by modelling for sediment (average $0.0000678 \mathrm{mg} / \mathrm{kg}$ ) were in agreement with those obtained bymeasurement, exceptfor 5 sampling points, namely Calimanesti, Daesti, Ramnicu Valcea , Govora and Babeni, where higher values were registered, of $0.0163 \mathrm{mg} /$ $\mathrm{kg}, 0.0255 \mathrm{mg} / \mathrm{kg}, 0.0157 \mathrm{mg} / \mathrm{kg}, 0.0255 \mathrm{mg} / \mathrm{kg}$ and 0.0157 $\mathrm{mg} / \mathrm{kg}$ respectively. From the modelled values was observed a tendency bytransfer of benzene in the section air, with values between 0.002 to $0.026 \mathrm{ng} / \mathrm{m}^{3}$; insignificant amount is taken 

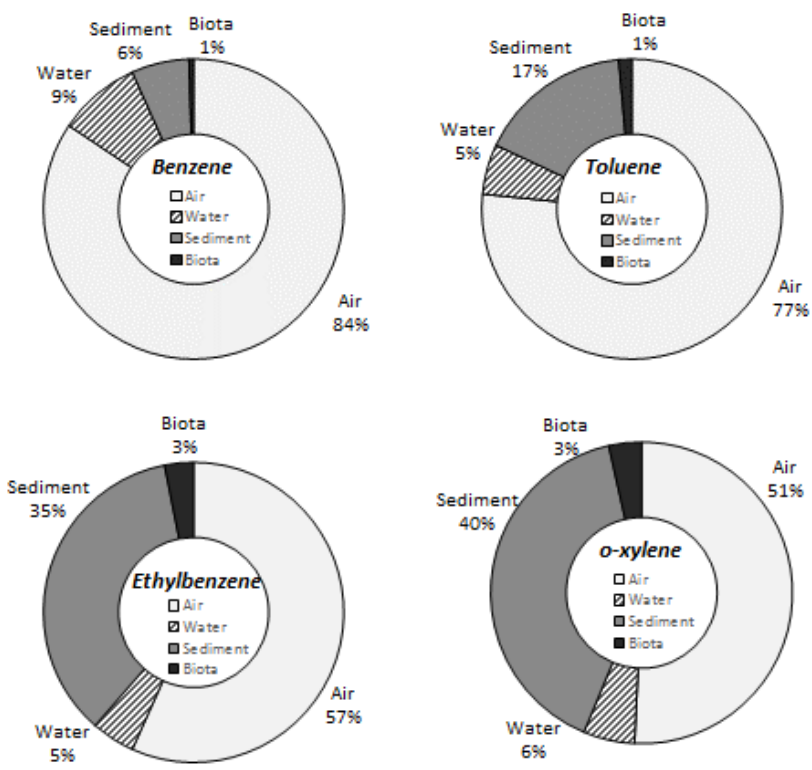

Fig. 4. The transfer of BTEX in the environmental compartments (air, water, sediment, and biota) of the Olt River (middle and lower basin) areal
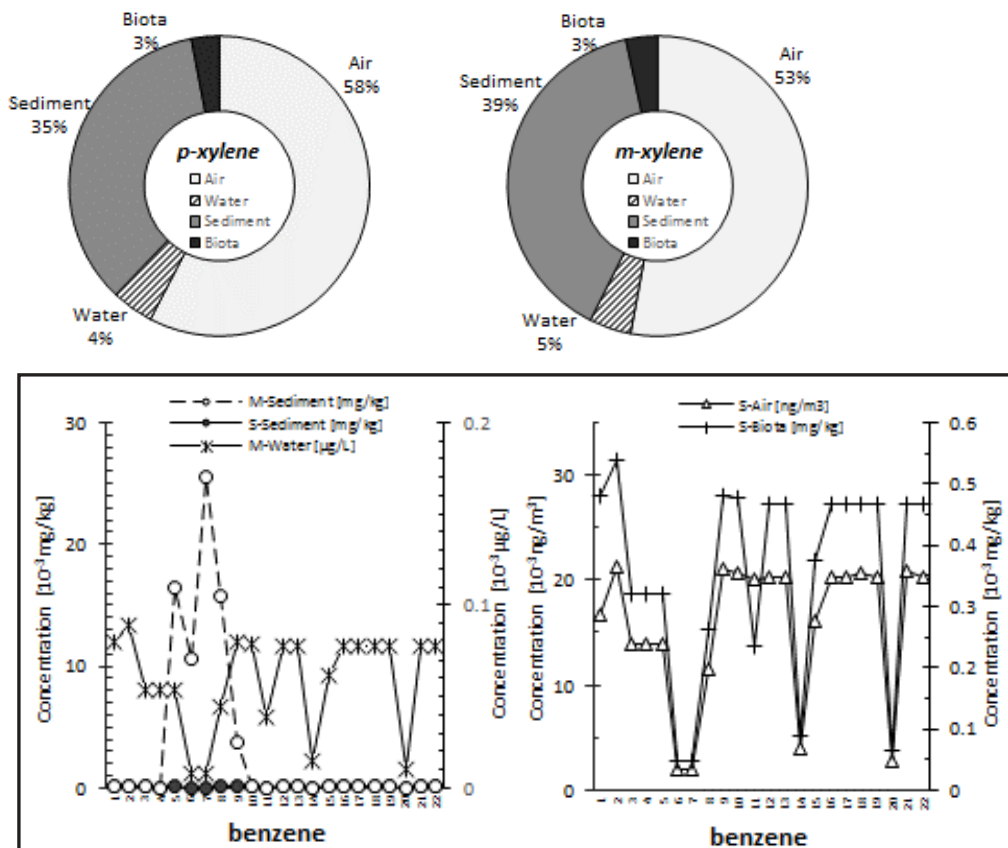

Fig. 5. Measured/predicted concentration of benzene in environmental compartments

from the biota compartment, with average value of 0.000353 $\mathrm{mg} / \mathrm{kg}$.

By simulation, the results for ethylbenzene (Fig. 6) in sediment (average $0.001392 \mathrm{mg} / \mathrm{kg}$ ) were in agreement with those obtained by measurement $(<0.005 \mathrm{mg} / \mathrm{kg})$, except for 6 sampling points, namely Calimanesti, Daesti, Ramnicu Valcea, Govora and lonesti, where highervalues were obtained, of $0.0267 \mathrm{mg} / \mathrm{kg}, 0.0157 \mathrm{mg} / \mathrm{kg}, 0.0208 \mathrm{mg} / \mathrm{kg}, 0.0197 \mathrm{mg} / \mathrm{kg}$ and $0.0201 \mathrm{mg} / \mathrm{kg}$ respectively. From the modelled values was observed a tendency by transfer of ethylbenzene in the section air, with values between 0.02158 to $0.03762 \mathrm{ng} / \mathrm{m}^{3}$; low amountsis taken from the biota compartment, with average value of $0.007278 \mathrm{mg} / \mathrm{kg}$.

For m-xylene (Fig. 7), the values obtained by modelling for sediment (average $0.0014 \mathrm{mg} / \mathrm{kg}$ ) were in agreement with those obtained by measurement $(<0.003)$, except for 4 sampling points, namely Govora, Dragasani, Izbiceni and Ipotesti where $0.137 \mathrm{mg} / \mathrm{kg}$ were registered. From the simulation was observed a tendency by transfer of $m$-xylene in the section air, with an average value of $0.025412 \mathrm{ng} / \mathrm{m}^{3}$; low amount is taken from the biota compartment, with average value of $0.007406 \mathrm{mg} / \mathrm{kg}$.

The results achieved for 0-xylene (Fig. 8) in sediment (average $0.001273 \mathrm{mg} / \mathrm{kg}$ ) were in high agreement with the ones obtained by measurement $(<0.003$, the quantification limit of the method), except for Babeni sampling point where a value of $0.0069 \mathrm{mg} / \mathrm{kg}$ was obtained. The simulation also showed the tendency transfer of 0-xylene in the section air, with an average value of $0.0001 \mathrm{ng} / \mathrm{m}^{3}$; low amount is taken from the biota compartment, with average value of 0.006791 $\mathrm{mg} / \mathrm{kg}$.

For p-xylene (Fig. 9), the values obtained by modelling for sediment (average $0.001326 \mathrm{mg} / \mathrm{kg}$ ) were in agreement with those obtained by measurement $(<0.003 \mathrm{mg} / \mathrm{kg})$, except for 4 sampling points, namely Ramnicu Valcea, Babeni, Zavideni, Danube-downstream the OltRiver after flowing in the Danube Riverwhere higher values were registered, of $0.0102 \mathrm{mg} / \mathrm{kgand}$ $0.0187 \mathrm{mg} / \mathrm{kg}$. From the modelled values was observed a tendency by transfer of $p$-xylene in the section air, with values bellow $0.0001 \mathrm{ng} / \mathrm{m}^{3}$; low amount is taken from the biota compartment, with average value of $0.006977 \mathrm{mg} / \mathrm{kg}$.

In case of toluene (Fig. 10), the values obtained by simulation for sediment (average $0.000946 \mathrm{mg} / \mathrm{kg}$ ) were in almost agreement with those obtained by measurement 

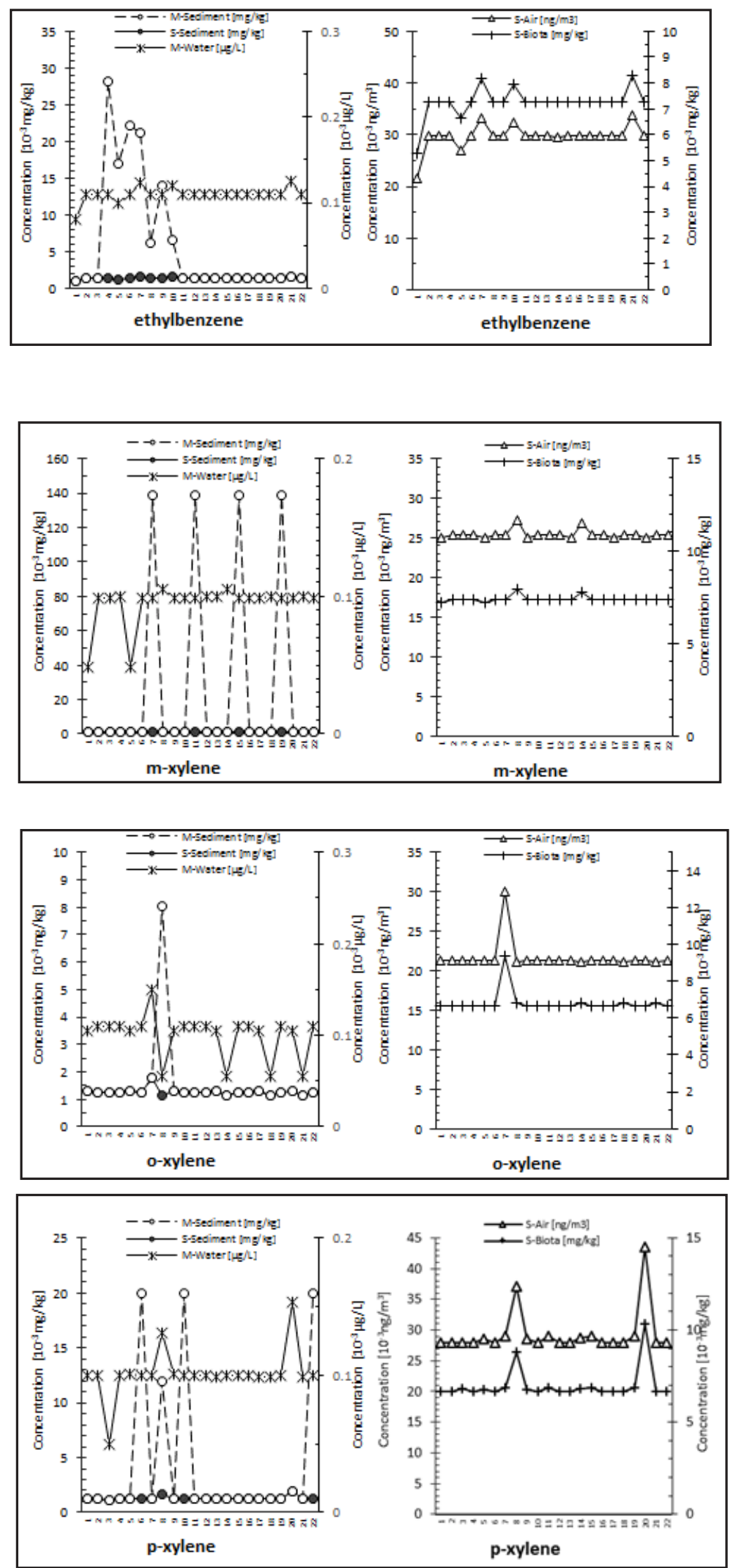

Fig. 6. Measured/predicted concentration of ethylbenzene in environmental compartments

Fig. 7. Measured/predicted concentration of $m$-xylene in environmental compartments

Fig. 8. Measured/predicted concentration of o-xylenein environmental compartments

Fig. 9. Measured/predicted concentration of $p$-xylene in environmental compartments
(<0.003 mg/kg), except for Calimanesti $(0.1491 \mathrm{mg} / \mathrm{kg}$ ), Daesti $(0.0121 \mathrm{mg} / \mathrm{kg})$, Ramnicu Valcea $(0.0147 \mathrm{mg} / \mathrm{kg})$, Govora $(0.0204 \mathrm{mg} / \mathrm{kg})$, Ionesti $(0.0121 \mathrm{mg} / \mathrm{kg})$, Frunzaru $(0.0102 \mathrm{mg} / \mathrm{kg})$, Strejesti $(0.0177 \mathrm{mg} / \mathrm{kg})$, Islaz $(0.0385 \mathrm{mg} /$ $\mathrm{kg})$, Danube -upstream the Olt River before flowing in the Danube River $(0.079 \mathrm{mg} / \mathrm{kg})$, and Danube -downstream the
Olt River after flowing in the Danube River $10.0227 \mathrm{mg} /$ $\mathrm{kg}$ ) where higher values were registered, of $0.0102 \mathrm{mg} / \mathrm{kg}$ and $0.0187 \mathrm{mg} / \mathrm{kg}$.From the modelled values was observed a tendency by transfer of toluene in the section air, with values bellow $0.000197 \mathrm{ng} / \mathrm{m}^{3}$; low amount is taken from the „biota” compartment, with average value of $0.003879 \mathrm{mg} / \mathrm{kg}$. 


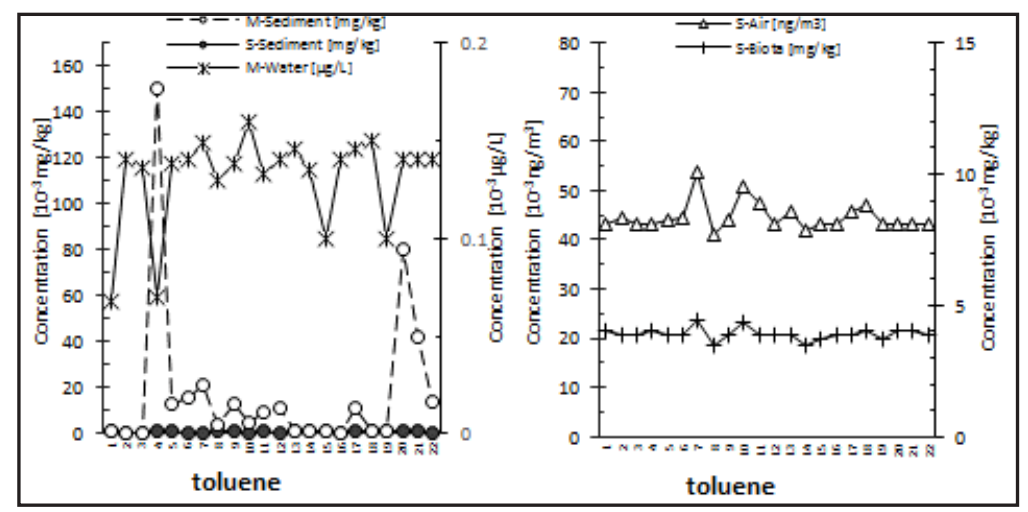

Fig. 10. Measured/predicted concentration of toluene in environmental compartments

\section{Conclusions}

The applied model based on fugacity generated realistic indicative values for transfer of pollutants in environmental compartments of interest, respectively, air, sediment, and biota. The modelling values obtained for the sediment compartment are comparable and compatible with the values obtained through analytical measurements, which gives a quick indication of the pollution level with the precise pollutant in the studied compartment;

The modelling highlighted the trend of transfer in the air compartment of COV and BTEX in the sedimentcompartment It highlighted the tendency of transfer of the volatile organic compounds, 1,2-dichloroethane and perchlorethylene $(65.0 \%$ and $68 \%$ respectively), known to be volatile compounds, in the air compartment.

For the volatile aromatic hydrocarbons (BTEXs), a transfer tendency in the air of $84.3 \%$ benzene, $77 \%$ toluene, $58 \% \mathrm{~m}$-xylene, $57 \%$ ethylbenzene, $53 \% \mathrm{~m}$-xylene and $51 \%$ 0 -xylene was achieved.

For the validation of the modelling, the values obtained for the sediment factor were considered, as these types of samples could be analyzed as real samples in the laboratory. The simulated and measured data were in agreement with except of few cases, when measured values were lowly higher then the estimaed ones.

For a quickest and easiest applicability, the applied model did not make detailed calculations to include river flow, so the dilution factor can vary from one monitoirng compaignes to another, depending on the annual meteorological factors.

Using this type of modelling, that imply reduce number of analytical measurements, a fingerprint of environmentalpolltion can be estimated, supplying thus conclusive indications for a rapid risk assessment and a base for actions and preventive measures.

Acknowledgments: This work is part of the project PN 18120303 Assessing the impact of waste water discharges on the environment through advanced analytical investigations based on nuclear and other related techniques financed by the Romanian Ministry of Research and Innovation.

\section{References}

1. M. IORDACHE, L. R. POPESCU, L.F. PASCU, I. IORDACHE, Progress of Cryogenics and Isotopes Separation, 18(1), 5-20 (2015).

2. ALAMDAR, H.J. SYED, R. N MALIK, A. KATSOYANNIS, J. LIU, J. LI, G. ZHANG, K.C. JONES, Science of the Total Environment, 470-471, 733741 (2014).
3. R. DYCK, R. SADIQ, M.J. RODRIGUEZ, S. SIMARD, R. TARDIF, Water research, 45, 5084-5098 (2011).

4. V.R. VASQUEZ, J. CURREN, S.-L. LAU, M. K. STENSTROM, I.H. SUFFET, Science of the Total Environment, 409, 4010-4015 (2011).

5. C. WARREN, D. MACKAY, M. WHELAN, K. FOX, Chemosphere 61, 1458-1467(2005).

6. S. GOKGOZ-KILIC, M.M. ARAL, Journal of Environmental Management, 88, 448-457 (2008).

7. J. DONG, H. GAO, S. WANG, H. YAO, M. MA, Ecotoxicology and Environmental Safety, 72, 1950-1956 (2009).

8. Yi-Z. ZHANG, X.-F. SONG, A. KONDOH, J. XIA, C.-Y. TANG, Water research, 45(1), 292-302 (2011).

9. D. MACKAY, S. PATERSON, Environmental Science Technology, 15(9), 1006-1014(1981)

10 .D. MACKAY, The Fugacity Approach, Lewis Publishers Inc., (1991). 11. J. HO KIM, B. K. KWAK, C. B. SHIN, W. J. JEON, H.-S. PARK, K. CHOI, J. YI, Appl. Math. Model., 34, 2279-2290 (2010).

12. L. HUGHES, D. MACKAY, D. E. POWELL, J. KIM, Chemosphere, 87, 118-124(2012)

13. D. MACKAY, M. JOY, S. PATERSON, Chemosphere, 12, 981-997 (1983).

14. D. MACKAY, S. PATERSON, M. JOY, Chemosphere, 12, 1193-1208 (1983).

15. D. MACKAY, L. HUGHES, D. E. POWELL, J. KIM, Chemosphere, 111, 359-365 (2014).

16. Y. LIU, L. CHANGYOU, B. ANDERSON, S. ZHANG, S. XIAOHONG, S. ZHAO, Chemosphere 176, 117-124 (2017).

17. S. CUI, Q. FU, T.-X. LI, W.-L. MA, D. LIU, M. WANG, Water research, 8(8), (334), 1-13(2016).

18. J. AO, J. CHEN, F. TIAN, X. CAl, Chemosphere, 74, 370-376 (2009). 19. D. MACKAY, J. A. ARNOT, F. WANIA, R. E. BAILEY, Integr. Environ. Assess. Manag., 7, 248-55 (2011).

20. K. S. PITZER, J ournal of Chemical Education, 61, 104-107 (1984). 21. D. VALLERO, Fundamentals of Air Pollution, Ed $5^{\text {th }}$, Chapter 18, 437-473(2018).

22. D. POPESCU, D. COSTINEL, R.E.I. IONETE, D. AXENTE, Isotopes. in Environ. and Health Studies, 50, 461-744 (2014).

23.D. FLORESCU, R.E. IONETE, C. SANDRU, A. IORDACHE, M. CULEA, Romanian J ournal of Physics, 56(7-8), 1001-1010 (2011).

24.CHIVU, O. R., SEMENESCU, A.,BABIS, C., IACOBESCU, G., NEGOITA, O.D., GRADINARU, S., Rev. Chim. (Bucharest) 68, no. 8, 2017, p. 18581863

25.IORDACHE,M., POPESCU, L. R., NEAMTU, S., PASCU,L.F., IORDACHE, I. Rev. Chim. (Bucharest), 67, no. 6, 2016, p. 1186-1190 26. SEMENESCU, A., BABIS, C., IACOBESCU, G., ROGOBETE, M., RACUCIU, C., NEN, M., CHIVU, O.R., GHIMIS, S. S., Rev. Chim. (Bucharest), 68, no. 4,2017, p. 772-775

Manuscript in received: 22.04 .2019 